\title{
REFERENCES
}

Dhingra, D. R. (1933). Biochem. J. 27, 851.

Faltin, A. \& Dedinszky, G. (1930). Rep. Hung. agric. Exp. Sta. 33, 62.

Heiduschka, A. \& Steinrock, A. (1921). J. prakt. Chem. (2), $102,241$.

Hilditch, T. P. (1940). Chemical Constitution of Natural Fats. London: Chapman and Hall, Ltd.

— \& Dean, H. K. (1933). Biochem. J. 27, 889.

- \& Jasperson, H. (1941). J. Soc. chem. Ind., Lond., $60,305$.

\& Longenecker, H. E. (1937). Biochem. J. 31, 1805.

—— Sleightholme, J. J. (1930). Biochem. J. 24, 1098.

Knowles, F. \& Urquahart, J. C. (1924). Analyst, 49, 509.
Laxa, O. (1927). Ann. Falsif., Paris, 20, 462.

- (1931). Ann. Falsif., Paris, 24, 87.

Longenecker, H. E. (1937). J. Soc. chem. Ind., Lond., $56,199 \mathrm{~T}$.

de la Mare, P. B. D. \& Shorland, F. B. (1944). Nature, Lond., 158, 380.

Mitchell, J. H., Kraybill, H. R. \& Zscheille, F. P. (1943). Industr. Engng Chem. (Anal. ed.), 15, 1.

Riemenschneider, R. W. \& Ellis, N. R. (1936). J.biol. Chem. 118, 219.

Shinowara, H. Y. \& Brown, J. B. (1938). J. Amer. chem. Soc. 60, 2734.

Shorland, F. B. (1944). Nature, Lond., 153, 168.

Smith, J. A. B. \& Chibnall, A. C. (1932). Biochem. J. 26, 218.

\section{The Stabilization and Estimation of Pyruvic Acid in Blood Samples}

\author{
By C. LONG, Department of Biochemistry, The Queen's University, Belfast
}

(Received 21 September 1944)

Two methods are available for assessing the aneurin (vitamin $B_{1}$ ) nutritional level of the body. The first of these involves the determination of aneurin itself in blood or urine, especially after test doses, and has met with only partial success. (For a review of the literature, see Bicknell \& Prescott, 1942.) The other procedure depends upon the fact that pyruvic acid, an intermediary in carbohydrate metabolism, is utilized by the tissues at a rate which is largely determined by their co-carboxylase (aneurin pyrophosphoric ester) content; thus when dietary aneurin is inadequate and the tissues contain suboptimal amounts of co-carboxylase, pyruvate is only slowly metabolized and its concentration in the blood tends to increase.

While pyruvate is readily estimated in proteinfree filtrates (Long, 1942), the concentration of pyruvic acid present in vivo in the blood is not easily determined since its value falls during the period following the drawing of the blood sample. Lu (1939) and Friedemann \& Haugen (1942) overcame this difficulty by deproteinizing the blood specimen as quickly as possible after withdrawal from the vein. Bueding \& Wortis (1940), however, did not find this method satisfactory, but claimed to have stabilized the level of blood pyruvate for a few minutes by means of iodoacetate. More recently, Golberg \& Gillman (1943) have shown that in the presence of both iodoacetate and fluoride the pyruvate level remains constant for $30 \mathrm{~min}$.

The aim of the present investigation has been to find some method of stabilizing, for a longer period, the pyruvate level of a blood sample at its initial value. This would allow the postponement of an estimation until a sufficient number of samples had accumulated; specimens might also be sent by post. This aim has been so successfully achieved that blood samples may now be kept at room temperature for at least 3 weeks without variation in the pyruvate level. The method of stabilization requires haemolysis at a slightly acid reaction in the presence of fluoride.

\section{FACTORS CONTROLLING CHANGES IN THE PYRUVIC ACID LEVEL OF SHED BLOOD Materials}

Na pyruvate. Prepared according to Peters (1938). A solution containing a known amount (about $5 \mu \mathrm{g}$.) in $2 \mathrm{ml}$. $10 \%$ trichloroacetic acid was used as a standard.

$\mathrm{Na}$ iodoacetate. Iodoacetic acid was neutralized with $40 \% \mathrm{NaOH}$ to $\mathrm{pH} 7 \cdot 5$. Final concentration in blood, $0 \cdot 2-2 \cdot 0 \%$.

Citrate buffers of suitable $\mathrm{pH}$ values. Citric acid monohydrate (mol. wt. 210$)(0.840 \mathrm{~g}$.), dissolved in about $1.5 \mathrm{ml}$. water, was treated with $40 \% \mathrm{NaOH}$ till the required $\mathrm{pH}$ was attained. One-fifth of the total volume was then pipetted into a tube and evaporated to dryness (see Methods (a)); this amount was used for each $10 \mathrm{ml}$. blood sample, giving a final concentration of $0.08 \mathrm{M}$.

Haemolytic agents. 'White' saponin (F. E. Becker and Co.) and thymol were used at final concentration 0.5 and $0.25 \%$ respectively. Cetyltrimethylammonium bromide ('Cetavlon') in solid form (75\%) and as a $7.5 \%$ solution was obtained from Imperial Chemical (Pharmaceuticals) Ltd. Final concentration $0.3 \%$. 
All other reagents were analytical specimens, the final concentration in blood being: oxalic acid $(0.05 \mathrm{M}), \mathrm{K}$ oxalate $(0.02$ and $0.01 \mathrm{M}), \mathrm{Na}$ citrate $(0.02 \mathrm{M})$ and $\mathrm{NaF}(0.1 \mathrm{M})$.

Blood from normal male subjects was used.

\section{Methods}

(a) Pretreatment of tubes to contain blood samples. Anticoagulants, with or without inhibitors, buffers and haemolytic agents, were introduced into test-tubes (graduated at $10 \mathrm{ml}$.) either as solids or in solution; in the latter case, the contents of the tubes were evaporated to dryness in vacuo on a boiling water-bath. The tubes were fitted with white rubber bungs, corks being unsuitable in view of the colorimetric procedure which followed, especially when the blood was acidified.

(b) Collection of blood samples. A $50 \mathrm{ml}$. syringe was filled with venous blood, a process lasting about $1 \mathrm{~min}$. Each tube was then filled to the $10 \mathrm{ml}$. mark and the contents vigorously shaken for about 10 sec. In general, the procedure up to this point lasted not more than $2 \mathrm{~min}$. This was considered satisfactory in view of the observation of Friedemann \& Haugen (1942) that the pyruvate level of untreated blood samples remains constant for $3 \mathrm{~min}$.

(c) Preparation of protein-free filtrates. $1 \mathrm{ml}$. blood was slowly. pipetted drop by drop, to ensure maximum drainage, into $4 \mathrm{ml} .12 .5 \%$ trichloroacetic acid and the mixture thoroughly shaken. The tube was allowed to stand $20 \mathrm{~min}$. before filtration. When a high blood pyruvate level was expected, less than $1 \mathrm{ml}$. blood was taken.

(d) Pyruvic acid content of the filtrate. The estimation was made on $2 \mathrm{ml}$. protein-free filtrate, the method being that of Long (1942) without modification. Briefly this depends on the conversion of the pyruvic acid into its 2:4-dinitrophenyl-hydrazone, followed by extraction of the latter first into ethyl acetate solution and then into aqueous $\mathrm{Na}_{2} \mathrm{CO}_{3}$; finally the $\mathrm{Na}_{2} \mathrm{CO}_{3}$ extract was treated with excess $\mathrm{NaOH}$ and the intensity of the red-brown colour developed was determined photometrically. Blank determinations with $2 \mathrm{ml} .10 \%$ trichloroacetic acid were always simultaneously performed and the accuracy of the method was frequently checked using $\mathrm{Na}$ pyruvate standards.

(e) Recovery of pyruvic acid. A blood sample was found to contain $1.01 \mathrm{mg}$. pyruvic acid/100 ml. Pyruvic acid (as $\mathrm{Na}$ pyruvate) was added to the sample in amount equivalent to $0.50 \mathrm{mg} . / 100 \mathrm{ml}$. Total pyruvic acid was determined and found to be $1.515 \mathrm{mg} . / 100 \mathrm{ml}$. Difference, $0.505 \mathrm{mg}$.; recovery, $101 \%$.

(f) $\mathrm{pH}$ of blood samples. In those experiments in which the blood was acidified with citrate buffer, the final $\mathrm{pH}$ of the sample was often determined. The author wishes to thank Prof. D. C. Harrison for making these determinations with the glass electrode apparatus.

\section{Results}

The effect produced by the anticoagulant. Wilkins, Weiss \& Taylor (1938) first showed the rapid disappearance of pyruvate from oxalated blood, an observation which has been confirmed by Bueding \& Wortis (1940). A destruction of pyruvate under similar conditions has also been observed in the present investigation (Table 1).

When citrate is used as anticoagulant, however, the rate of pyruvate disappearance during the first
Table 1. Disappearance of pyruvic acid from oxalated blood

\begin{tabular}{cc}
\multicolumn{2}{c}{0.02 M-oxalate present. } \\
Time & $\begin{array}{c}\text { Pyruvic acid } \\
\text { (min.) }\end{array}$ \\
$2 \cdot 2$ & 0.91 \\
$3 \cdot 3$ & 0.86 \\
$4 \cdot 5$ & 0.78 \\
$7 \cdot 6$ & 0.69 \\
13.4 & 0.47 \\
21.6 & 0.36 \\
31.6 & 0.28
\end{tabular}

$30 \mathrm{~min}$. is much reduced (Table 2) as compared with oxalate. Moreover, this difference in behaviour of the two anticoagulants is even greater when the experiment is continued for some days (Table 3).

Table 2. Pyruvate disappearance from oxalated and citrated blood

\begin{tabular}{|c|c|c|}
\hline \multirow{2}{*}{$\begin{array}{l}\text { Time } \\
\text { (min.) }\end{array}$} & \multicolumn{2}{|c|}{ Pyruvic acid (mg./100 ml.) } \\
\hline & $0.02 \mathrm{M}$-oxalate & $0.02 \mathrm{M}$-citrate \\
\hline $2 \cdot 7$ & $0 \cdot 83$ & - \\
\hline $5 \cdot 3$ & - & $0 \cdot 81$ \\
\hline $7 \cdot 8$ & 0.63 & - \\
\hline $12 \cdot 7$ & - & 0.77 \\
\hline $15 \cdot 0$ & 0.46 & - \\
\hline $21 \cdot 4$ & $0 \cdot 31$ & - \\
\hline $27 \cdot 1$ & - & 0.73 \\
\hline
\end{tabular}

Table 3. Blood pyruvate level after some days at room temperature

\begin{tabular}{ccc} 
Time & \multicolumn{2}{c}{ Pyruvic acid (mg./100 ml.) } \\
\cline { 2 - 3 } (min.) & 0.02 M-oxalate & 0.02 M-citrate \\
7.0 & 0.70 & - \\
10.1 & 0.56 & - \\
16.5 & - & 0.65 \\
18.6 & 0.43 & - \\
(days) & - & 0.63 \\
1 & & \\
2 & 0.48 & 0.93 \\
3 & 0.39 & 1.48 \\
4 & 0.23 & 6.70 \\
8 & 0.34 & 15.7 \\
& 4.08 & 17.6
\end{tabular}

Thus, after standing for $24 \mathrm{hr}$., citrated blood shows a definite increase in pyruvate concentration over the initial value and this effect continues for about a week; in oxalated blood, on the other hand, the pyruvate concentration continues to fall during the first 3 days and then only slowly begins to rise. This increase in pyruvate concentration is not due to bacterial action, since identical figures have been observed in the presence of $0.5 \%$ phenol.

With oxalate $0.02 \mathrm{M}$ has been found to be more effective than $0.01 \mathrm{M}$ in preventing this rise in pyruvate concentration (Table 4).

The effect of fluoride. The experiment in Table 3 indicates that two separate reactions, one destroying and another producing pyruvic acid, may take place 
Table 4. The effect of oxalate concentration on the disappearance of pyruvate from blood

\begin{tabular}{ccc} 
Time & \multicolumn{2}{c}{ Pyruvic acid (mg./100 ml.) } \\
\cline { 2 - 3 } (min.) & 0.01 m-oxalate & 0.02 M-oxalate \\
3.6 & 0.58 & - \\
6.9 & -5.45 \\
10.4 & 0.26 & $-\overline{26}$ \\
13.8 & - & - \\
21.4 & 0.25 & 0.24 \\
29.1 & - & \\
(days) & & 0.24 \\
1 & 0.24 & 0.13 \\
2 & 0.22 & 0.11 \\
3 & 0.18 & 0.23 \\
4 & 1.55 & 0.92 \\
5 & 2.92 & 3.41 \\
8 & 5.70 &
\end{tabular}

in shed blood. The most likely reactions concerned are respectively :

(i) Pyruvate + triosephosphate $\rightleftharpoons$ lactate + 3-phosphoglycerate,

(ii) 3-Phosphoglycerate $\rightleftharpoons 2$-phosphoglycerate $\rightleftharpoons$ phosphopyruvate $\rightarrow$ pyruvate.

Support for reaction (i) is found in the iodoacetate inhibition of pyruvate disappearance (Bueding \& Wortis, 1940), in the approximate equivalence of pyruvate disappearance and lactate production in the presence of NaF (Bueding \& Goodhart, 1941) and in the relevant observations of Dische (1936-7), Lu \& Needham (1939) and Harris \& Elgert (1941). There is also much evidence in favour of reaction (ii). First, oxalate is known to inhibit the dephosphorylation of phosphopyruvate in muscle extracts (Lohmann \& Meyerhof, 1934). This accords well with the observation of Friedemann \& Haugen (1942) that during the first few minutes after withdrawal from the vein, pyruvate disappears rapidly from oxalated as compared with untreated blood.

\section{Table 5. Inhibition of pyruvate formation by fluoride}

\begin{tabular}{|c|c|c|c|c|c|}
\hline & $\begin{array}{l}\text { Pyruv } \\
\text { (mg./1 }\end{array}$ & 00 ml.) & & $\begin{array}{c}\text { Pyruy } \\
\text { (mg./l }\end{array}$ & $\begin{array}{l}c \text { acid } \\
0 \mathrm{ml} .)\end{array}$ \\
\hline $\begin{array}{c}\text { Time } \\
\text { (min.) }\end{array}$ & $\begin{array}{l}0.02 \mathrm{M}- \\
\text { oxalate }\end{array}$ & $\begin{array}{c}0.02 \mathrm{M}- \\
\text { oxalate } \\
+0.1 \mathrm{M}- \\
\mathrm{NaF}\end{array}$ & $\begin{array}{l}\text { Time } \\
\text { (min.) }\end{array}$ & $\begin{array}{l}0.02 \mathrm{M}- \\
\text { citrate }\end{array}$ & $\begin{array}{c}0.02 \mathrm{M}- \\
\text { citrate } \\
+0.1 \mathrm{M}- \\
\mathrm{NaF}\end{array}$ \\
\hline $\begin{array}{l}6 \cdot 6 \\
9 \cdot 0\end{array}$ & $\overline{0.79}$ & $\begin{array}{c}0.81 \\
-\end{array}$ & $\begin{array}{l}4 \cdot 1 \\
7 \cdot 8\end{array}$ & $\bar{I} \cdot \overline{04}$ & $\underline{0.91}$ \\
\hline 11.5 & - & 0.70 & $11 \cdot 2$ & - & 0.59 \\
\hline $13 \cdot 8$ & 0.66 & - & $15 \cdot 4$ & 0.97 & - \\
\hline $21 \cdot 4$ & - & 0.45 & $23 \cdot 1$ & - & 0.57 \\
\hline $25 \cdot 2$ & $0 \cdot 37$ & - & $31 \cdot 7$ & 0.92 & - \\
\hline $\mathbf{3 3 \cdot 5}$ & 一 & $0 \cdot 37$ & $35 \cdot 7$ & - & 0.56 \\
\hline (days) & & & (days) & & \\
\hline 1 & 0.39 & 0.32 & 1 & 2.92 & 0.55 \\
\hline 3 & 0.29 & 0.24 & 2 & $12 \cdot 0$ & 0.52 \\
\hline 7 & $1 \cdot 72$ & $0 \cdot 28$ & 3 & $14 \cdot 6$ & 0.51 \\
\hline 10 & 4.49 & 0.46 & & & \\
\hline
\end{tabular}

Thus, in oxalated blood, pyruvate is utilized by reaction (i), its formation by reaction (ii) being largely inhibited; reaction (ii), on the other hand, readily takes place in $0.02 \mathrm{M}$-citrated blood and partly compensates for the pyruvate utilization by reaction (i) during the first $\mathbf{3 0} \mathrm{min}$., so that a slower rate of pyruvate disappearance is observed. As would be expected, $0.02 \mathrm{M}$-oxalate has proved to be more effective than 0.01 M-oxalate as an inhibitor of pyruvate formation by reaction (ii) (Table 4).

Further evidence for reaction (ii) is to be found in the well-marked inhibition of pyruvate formation in the presence of $\mathrm{NaF}$ (Table 5), though, as might be expected, this is most clearly shown with citrated blood where the reaction is not masked by oxalate inhibition. $\mathrm{NaF}$ is well known to inhibit the conversion of 2-phosphoglyceric to phosphopyruvic acid (Lohmann \& Meyerhof, 1934).

The use of iodoacetate for stabilizing blood pyruvate. Bueding \& Wortis (1940), in an attempt to inhibit the oxido-reduction between pyruvate and triosephosphate in shed blood, collected their samples in a syringe containing iodoacetate; concentrations from 0.2 to $2.0 \%$ were effective in preventing the disappearance of pyruvate during the first few minutes. It cannot be said, however, that stabilization was achieved, since the published figures show a slow upward trend in the level of the blood pyruvate, the value after $30 \mathrm{~min}$. having risen by $3-20 \%$. This behaviour has been amply confirmed by Golberg \& Gillman (1943). It now became of interest to ascertain how blood samples treated with iodoacetate would behave on standing for longer periods. In Table 6 typical experiments with three concentrations of iodoacetate are recorded.

Considering first the effect of $1 \%$ iodoacetate (Table $6(a)$ ), it will be seen that after standing for a day the blood pyruvate level has fallen considerably, indicating that at this concentration iodoacetate does not inhibit oxido-reduction completely ; after standing for a few more days, however, the pyruvate concentration again begins to rise, showing that the breakdown of phosphoglycerate is becoming marked. $0.2 \%$ iodoacetate (Table 6 (b)) shows the same behaviour; $2 \%$ iodoacetate, on the other hand, has proved to be effective in inhibiting the dismutation for some days. An unsatisfactory feature of iodoacetate inhibition, however, has been pointed out by Friedemann \& Haugen (1942), who observed that the initial blood pyruvate level was higher in the presence of iodoacetate than in its absence; in Table 6 (b) it may be noted that the initial level is higher in the presence of $2 \%$ as compared with $0.2 \%$ iodoacetate.

Golberg \& Gillman (1943) added NaF (approx. $0.1 \mathrm{M}$ ) as well as $\mathrm{Na}$ iodoacetate to their blood samples and claimed that under these conditions the pyruvate concentration was stabilized for 
Table 6. The effect of iodoacetate, with and without fluoride, on the blood pymuvate level

$0.02 \mathrm{M}$-oxalate present.

(a) $1 \% \mathrm{Na}$ iodoacetate

Pyruvic acid (mg./100 ml.)

\begin{tabular}{|c|c|c|c|}
\hline $\begin{array}{l}\text { Time } \\
\text { (min.) }\end{array}$ & $\begin{array}{c}\text { Iodoacetate } \\
\text { absent }\end{array}$ & $\begin{array}{c}1 \% \\
\text { iodoacetate }\end{array}$ & $\begin{array}{c}1 \% \\
\text { iodoacetate, } \\
0 \cdot 1 \mathrm{M}-\mathrm{NaF}\end{array}$ \\
\hline & 0.79 & - & - \\
\hline $\begin{array}{l}13 \cdot 8 \\
16 \cdot 4\end{array}$ & $\underline{0.66}$ & $\overline{1.35}$ & $\bar{z}$ \\
\hline 18.8 & $=$ & - & 1.31 \\
\hline $25 \cdot 2$ & 0.37 & - & - \\
\hline 27.7 & - & 1.39 & - \\
\hline $30 \cdot 7$ & - & - & 1.46 \\
\hline \multicolumn{4}{|l|}{ (days) } \\
\hline 1 & $0: 39$ & 0.76 & 0.65 \\
\hline 4 & 0.27 & 0.87 & 0.69 \\
\hline 7 & 1.72 & 1.04 & 0.83 \\
\hline 10 & $4 \cdot 50$ & $1 \cdot 31$ & 0.96 \\
\hline
\end{tabular}

(b) 0.2 and $2 \% \mathrm{Na}$ iodoacetate Pyruvic acid (mg./100 ml.)

\begin{tabular}{|c|c|c|c|c|c|}
\hline $\begin{array}{l}\text { Time } \\
\text { (min.) }\end{array}$ & $\begin{array}{l}\text { Iodo- } \\
\text { acetate } \\
\text { absent }\end{array}$ & $\begin{array}{c}0.2 \% \\
\text { iodo- } \\
\text { acetate }\end{array}$ & $\begin{array}{c}0.2 \% \\
\text { iodo- } \\
\text { acetate, } \\
0 \cdot 1 \mathrm{M}- \\
\mathrm{NaF}\end{array}$ & $\begin{array}{c}2 \% \\
\text { iodo- } \\
\text { acetate }\end{array}$ & $\begin{array}{c}2 \% \\
\text { iodo- } \\
\text { acetate } \\
0 \cdot 1 \mathrm{M}- \\
\mathrm{NaF}\end{array}$ \\
\hline 6.9 & 0.59 & - & - & - & - \\
\hline $10 \cdot 1$ & - & 0.78 & - & - & - \\
\hline 15.9 & $0 \cdot 30$ & - & - & - & - \\
\hline $19 \cdot 1$ & - & - & 0.76 & - & - \\
\hline 22.1 & - & - & - & 0.98 & - \\
\hline $25 \cdot 1$ & - & - & - & - & 0.98 \\
\hline 30.0 & 0.18 & - & - & - & - \\
\hline \multicolumn{6}{|l|}{ (days) } \\
\hline .1 & 0.12 & 0.38 & 0.22 & 1.21 & 0.43 \\
\hline 4 & 1.53 & 0.32 & 0.16 & - & 0.55 \\
\hline 7 & $6 \cdot 30$ & 1.09 & 0.52 & 1.20 & 0.63 \\
\hline
\end{tabular}

30 min. at a level about $10 \%$ higher than the initial value. These conditions have also been examined in the present work (Table 6), and it will be seen that during the first few days the pyruvate level falls at all iodoacetate concentrations and later rises, approaching the initial value again after about a week. In view of the results obtained, the iodoacetate method has not been further investigated.

The pyruvate level as a function of the reaction of the blood. Since the two reactions involving pyruvate in shed blood, viz. oxido-reduction with triosephosphate and dephosphorylation of phosphopyruvate, both require enzyme systems, it was considered that a change of $\mathrm{pH}$ from neutrality might lead to enzyme inactivation and perhaps therefore to a stabilization of the blood pyruvate level. Encouraging results have been obtained on acidifying the blood sample. Table 7 compares the effect of $0.05 \mathrm{M}-\mathrm{Na}$ oxalate and $0.05 \mathrm{M}$-oxalic acid. During the first $30 \mathrm{~min}$. the oxido-reduction is completely inhibited and, on standing, the breakdown of phosphopyruvate is largely prevented.
Table 7. Effect of acidity on the blood pyruvate level

Time
(min.)
$11 \cdot 8$
$14 \cdot 2$
$20 \cdot 4$
$22 \cdot 0$
$29 \cdot 9$
$31 \cdot 6$
(day8)
1
2
5

\begin{tabular}{|c|c|}
\hline \multicolumn{2}{|c|}{ Pyruvic acid (mg./100 ml.) } \\
\hline $0.05 \mathrm{M}-\mathrm{Na}$ oxalate & 0.05 m-oxalic acid \\
\hline 0.81 & - \\
\hline & 0.98 \\
\hline $0 \cdot 60$ & $\overline{0.99}$ \\
\hline 0.49 & - \\
\hline - & 0.99 \\
\hline $\begin{array}{l}0.42 \\
0.34 \\
6 \cdot 15\end{array}$ & $\begin{array}{l}0.84 \\
0.86 \\
1.03\end{array}$ \\
\hline
\end{tabular}

Further experiments of a more detailed nature have also been carried out with $0.08 \mathrm{M}$-citrate buffers of known pH (Table 8); these buffers have a very suitable $\mathrm{pH}$ range and at the same time serve as anticoagulant. In this particular experiment, the final pH of the blood was determined roughly on a small sample of the plasma, with indicators. It will be noted that the $\mathrm{pH} 4$ and 5 buffers are most effective in reducing the reaction rates. Unfortunately it was not possible to use buffers more acid than $\mathrm{pH} 4$ since partial precipitation occurred, rendering the blood unsuitable for pipetting.

\section{Table 8. Blood pyruvate levels at different degrees of acidity}

\begin{tabular}{|c|c|c|c|c|}
\hline $\begin{array}{c}\mathrm{pH} \text { of } 0.08 \mathrm{M} \text {-citrate } \\
\text { buffer used ... } \\
\text { Final pH of mixture... }\end{array}$ & $\begin{array}{l}7 \cdot 5 \\
7.5\end{array}$ & $\begin{array}{l}6 \cdot 0 \\
7 \cdot 1\end{array}$ & $\begin{array}{l}5 \cdot 0 \\
6 \cdot 1\end{array}$ & $\begin{array}{l}4.0 \\
5.2\end{array}$ \\
\hline Time & \multicolumn{4}{|c|}{ Pyruvic acid $(\mathrm{mg} . / 100 \mathrm{ml})}$. \\
\hline 3.6 & 0.87 & - & - & - \\
\hline 6.2 & - & $1 \cdot 14$ & - & 二 \\
\hline $9 \cdot 1$ & - & - & 1.08 & - \\
\hline 12.1 & 0.73 & - & - & - \\
\hline $15 \cdot \overline{1}$ & - & - & - & 0.99 \\
\hline 18.0 & - & $1 \cdot 17$ & - & - \\
\hline 20.7 & - & - & $1 \cdot 10$ & - \\
\hline 23.7 & $0 \cdot 68$ & - & - & - \\
\hline 26.8 & - & - & - & 0.93 \\
\hline \multicolumn{5}{|l|}{ (days) } \\
\hline 1 & $1 \cdot 18$ & $6 \cdot 31$ & $2 \cdot 29$ & 0.96 \\
\hline 2 & $11 \cdot 8$ & 6.01 & $2 \cdot 19$ & $1 \cdot 17$ \\
\hline 3 & $19 \cdot 0$ & $\mathbf{2 \cdot 8 7}$ & 1.67 & 1.35 \\
\hline 4 & $18 \cdot 4$ & $2 \cdot 80$ & $\mathbf{1} \cdot 60$ & 1.43 \\
\hline
\end{tabular}

The effect of haemolysis on the blood pyruvate level. Haemolysis of blood samples was investigated for two reasons. First, it is often found that enzyme systems contained in red cells, and bound in some way to the structure of the cell, lose most of their activity when dispersed by haemolysis. Secondly, it seemed likely that in experiments conducted at low $\mathrm{pH}$, the acid would more easily inactivate the enzymes in the absence of a cell structure. Harris \& Elgert (1941) have shown that the enzyme system 
causing the destruction of pyruvic acid in shed blood is contained within the red cells and further that cell suspensions haemolyzed by saponin or by freezing and thawing lose their ability to utilize pyruvate after $1 \mathrm{hr}$. at room temperature.

Different haemolytic agents have been employed in the present work with varying success. In an early experiment, crystalline thymol, finely powdered in a mortar, proved very satisfactory as a haemolytic agent and stabilized the blood pyruvate level for 4 days in the presence of a pH 4 buffer (Table 9). It will also be observed that, at neutral pH, the breakdown of phosphoglycerate appears to be completely inhibited by thymol haemolysis.

Table 9. Haemolysis by finely powdered thymol for stabilizing blood pyruvate at an acid reaction

\begin{tabular}{|c|c|c|c|}
\hline \multirow[t]{2}{*}{ buffer used } & $7: 5$ & $7 \cdot 5$ & $4 \cdot 0$ \\
\hline & \multicolumn{3}{|c|}{ Pyruvic acid (mg./100 ml.) } \\
\hline$\underset{\text { (min.) }}{\operatorname{Time}}$ & $\begin{array}{c}\text { Thymol } \\
\text { absent }\end{array}$ & $\begin{array}{l}0.25 \% \\
\text { thymol }\end{array}$ & $\begin{array}{l}0.25 \% \\
\text { thymol }\end{array}$ \\
\hline $2 \cdot 9$ & $0: 59$ & - & - \\
\hline $3 \cdot 8$ & - & - & $0 \cdot 69$ \\
\hline $11 \cdot 0$ & - & 0.44 & - \\
\hline $14 \cdot 2$ & - & - & 0.74 \\
\hline $21 \cdot 0$ & $0 \cdot 36$ & - & - \\
\hline $26 \cdot 6$ & 一 & - & 0.71 \\
\hline 29.7 & - & 0.30 & - \\
\hline (days) & & & \\
\hline 1 & $\mathbf{0 . 3 3}$ & $0 \cdot 27$ & 0.73 \\
\hline 2 & $5 \cdot 12$ & 0.22 & 0.74 \\
\hline 3 & $14 \cdot 3$ & 0.21 & 0.74 \\
\hline 4 & $16 \cdot 8$ & 0.21 & 0.73 \\
\hline
\end{tabular}

Unfortunately, a very great disadvantage associated with thymol haemolysis was the fact that the blood samples after standing some days both at neutrality and at acid pH lost their homogeneity and contained particles in suspension which necessitated the use of a pipette with a tip of wide bore. For this reason, therefore, experiments were made using saponin as haemolytic agent. These, however, were not successful, for it appeared that even the best procurable samples of 'white' saponin contained a yellow-brown pigment which interfered with' the colorimetric procedure; the extent of interference increased with the time the blood was kept.

In an attempt to find a more suitable haemolytic agent, various substances were examined, including cetyltrimethylammonium bromide ('Cetavlon'), which is used clinically as a detergent. This compound has proved to be an excellent haemolytic agent, the red cells being laked immediately by an amount equivalent to a final concentration of $0.3 \%$. Also.it does not suffer from the disadvantage noted above in the case of saponin, being quite colourless. Table 10 shows the effect of 'Cetavlon' at different pH values.

Biochem. 1944, 38
Table 10. Blood pyruvate levels in the presence of 'Cetavlon' as haemolytic agent $0.3 \%$ 'Cetavion' present.

$\mathrm{pH}$ of $0.08 \mathrm{M}$-citrate

$\begin{array}{llllll}\text { buffer used ... } & \ldots & 7.5 & 6.0 & 5.0 & 4.0\end{array}$

Final pH of mixture... $7.5 \quad 7.35 \quad 6.3 \quad 5.4$

\begin{tabular}{ccccc}
$\begin{array}{c}\text { Time } \\
\text { (days) }\end{array}$ & \multicolumn{3}{c}{ Pyruvic acid (mg./100 ml.) } \\
0 & 0.95 & 0.97 & 0.96 & 1.00 \\
1 & 0.58 & 1.01 & 0.97 & 0.97 \\
2 & 0.51 & 0.98 & 0.96 & 1.00 \\
3 & 0.52 & 0.92 & 1.02 & 1.00 \\
4 & 0.57 & 0.80 & 1.03 & 1.01 \\
21 & 2.11 & 1.78 & 1.74 & 1.23
\end{tabular}

It will be noted that the blood pyruvate level remains constant for 3-4 days with a $\mathrm{pH} 4$ or 5 buffer, for 2 days only with a pH 6 buffer and not at all at neutradity. In the caise of blood treated with a pH 4 buffer, the possibility of stabilizing the pyruvate level for longer periods by adding NaF suggested itself. This procedure was attended with great success and appears to be a most reliable method of stabilizing pyruvic acid in blood samples.

\section{DETAILS OF THE PROCEDURE FOR THE STABILIZATION AND ESTIMATION OF PYRUVIC ACID IN BLOOD}

Citric acid monohydrate (168 mg.), dissolved in about $0.5 \mathrm{ml}$. distilled water, is treated with $40 \%$ $\mathrm{NaOH}$ until pH 4 is reached. One-half the volume of this citrate buffer is pipetted into a test-tube. The buffer is then evaporated to dryness in vacuo on a boiling water-bath. To the dry residue are added $21 \mathrm{mg}$. $\mathrm{NaF}$ and $20 \mathrm{mg}$. 'Cetavlon' (75\%). The tube is then fitted with a white rubber bung. The contents of the tube appear to be quite stable; no deterioration has been found when the tube has been allowed to stand for a few weeks.

Blood is withdrawn from a vein in the ante-cubital fossa into a $5 \mathrm{ml}$. syringe, transferred to the collecting tube and shaken thoroughly. By this means the blood pyruvate level is stabilized.

For the estimation of pyruvic acid, $1 \mathrm{ml}$. of the blood sample is pipetted drop by drop into $4 \mathrm{ml}$. $12.5 \%$ trichloroacetic acid and vigorously shaken. After $20 \mathrm{~min}$. the mixture is filtered through a $7 \mathrm{~cm}$. filter paper (Whatman no. 1), about $3 \mathrm{ml}$. filtrate being obtained. $2 \mathrm{ml}$. of the protein-free filtrate are pipetted into a test-tube. Two other test-tubes are taken, one containing $2 \mathrm{ml}$. of a solution of standard $\mathrm{Na}$ pyruvate (about $5 \mu \mathrm{g}$.) in $10 \%$ trichloroacetic acid and the other containing $2 \mathrm{ml}$. $10 \%$ trichloroacetic acid (blank experiment). The rest of the procedure is carried out according to the method of Long (1942). The amount of pyruvic acid found in $2 \mathrm{ml}$. protein-free filtrate is multiplied by 
Table 11. Stabilization of the blood pyruvate level by 'Cetavlon'-haemolysis in the presence of citrate buffer, pH 4, and fluoride

$\begin{array}{cccc}\begin{array}{c}\text { Time } \\ \text { (days) }\end{array} & \begin{array}{c}\text { Pyruvic acid } \\ \text { (mg./100 ml.) }\end{array} & \begin{array}{c}\text { Time } \\ \text { (days) }\end{array} & \begin{array}{c}\text { Pyruvic acid } \\ \text { (mg./100 ml.) }\end{array} \\ 0 & 1.15 & 7 & 1 \cdot 16 \\ 1 & 1.15 & 10 & 1 \cdot 18 \\ 2 & 1.18 & 14 & 1.13 \\ 3 & 1.12 & 21 & 1 \cdot 14 \\ 4 & 1.15 & & \end{array}$

250 to give the pyruvic acid concentration in $\mathrm{mg} . / 100 \mathrm{ml}$. blood.

In an experiment using $10 \mathrm{ml}$. blood, the pyruvate level has been found to be quite constant for at least 3 weeks, as shown in Table 11. This pyruvate level' was identical with that observed when the blood sample, in the absence of 'Cetavlon', was precipitated immediately with trichloroacetic acid.

\section{SUMMARY}

1. The changes in pyruvic acid level of blood samples treated with different anticoagulants, inhibitors and haemolytic agents have been investigated. The results obtained are in harmony with the occurrence of the two following reactions:

(i) Pyruvate + triosephosphate $\rightleftharpoons$ lactate + 3-phosphoglyceratè,

(ii) 3-Phosphoglycerate $\rightleftharpoons$ 2-phosphoglycerate $\rightleftharpoons$ phosphopyruvate $\rightarrow$ pyruvate.

2. The detailed procedure for stabilizing and estimating pyruvic acid in blood samples is given. Stabilization is brought about by haemolysis with cetyltrimethylammonium bromide in the presence of fluoride and a pH 4 citrate buffer; the estimation is by means of the 2:4-dinitrophenyl-hydrazone.

\title{
REFERENCES
}

Bicknell, F. \& Prescott, F. (1942). The Vitamins in Medicine. London: Heinemann.

Bueding, E. \& Goodhart, R. (1941). J. biol. Chem. 141, 931. \& Wortis, H. (1940). J. biol. Chem. 133, 585.

Dische, Z. (1936-7). Enzymologia, 1, 288.

Friedemann, T. E. \& Haugen, G. E. (1942). J. biol. Chem. 144, 67.

Golberg, L. \& Gillman, T. (1943). S. Afr. J. med. Sci. $8,117$.
Harris, J. S. \& Elgert, S. E. (1941). Proc. Soc. exp. Biol., N.Y., 47, 321.

Lohmann, K. \& Meyerhof, O. (1934). Biochem. Z. 273, 60.

Long, C. (1942). Biochem. J. 36, 807.

Lu, G. D. (1939). Biochem. J. 33, 249.

_ \& Needham, .D. M. (1939). Biochem. J. 83, 1544.

Peters, R. A. (1938). Biochem. J. 32, 2031.

Wilkins, R. W., Weiss, S. F. \& Taylor, F. L. H. (1938). Proc. Soc. exp. Biol., N.Y., 38, 296.

\section{Preparation of Penicillin. Improved Method of Isolation*}

\author{
By J. C. ClAYTON, B. A. HEMS, F. A. ROBINSON, R. D. ANDREWS and R. F, HUNWICKE, \\ Glaxo Laboratories Ltd., Greenford, Middlesex
}

(Received 24 January 1944; deposited with the Royal Society 23 May 1944-23 September 1944)

Fleming (1929) noticed that a mould which had accidentally contaminated a plate culture of Staphylococcus aureus was surrounded by a clear ring of agar, which suggested that the mould had produced an antibiotic substance in its immediate neighbourhood. He made no attempt, however, to isolate this substance, to which he gave the name penicillin, and the first attempt to do so was made three years later by Clutterbuck, Lovell \& Raistrick (1932).

* This paper describes work completed by the end of 1942. Its publication has been delayed for security reasons. The authors are aware that considerable progress has been made in the preparation and isolation of penicillin since this preliminary work was carried out.
They confirmed Fleming's observations that penicillin was active against Gram-positive but not against Gram-negative organisms, and showed that it could be extracted by ether from aqueous solutions at pH 2. They gave details for growing the mould, now known as Penicillium notatum Westling, on a synthetic medium of Czapek-Dox type, instead of the broth media used by Fleming.

Widespread interest in penicillin was aroused by two papers published by Florey and his colleagues (Abraham, Chain, Fletcher, Florey, Gardner, Heatley \& Jennings, 1941; Chain, Florey, Gardner, Heatley, Jennings, Orr-Ewing \& Sanders, 1940), who described a method of preparing crude concen- 